УДК $21: 14+21.31 .35$

DOI: $10.32837 /$ apfs.v0i25.872

Світлана Михайлівна Повторева

професор кафедри філософії

Національний університет «Львівська політехніка», м. Львів, Україна

доктор філософських наук, професор

Іріна Іванівна Старовойтова

доцент кафедри філософії і методології пізнання

Одеський національний університет ім. .І.Мечнікова, м. Одеса, Україна

кандидат філософських наук, доцент

\title{
БОРОТЬБА МАГНАТІВ ОСТРОЗЬКИХ ПРИ ПІДТРИМЦІ ПРОТЕСТАНТІВ ЗА ЗБЕРЕЖЕННЯ ПРАВОСЛАВНОЇ ЦЕРКВИ: УРОКИ ІСТОРІї
}

\begin{abstract}
Анотація: Предметом дослідження статті є релігійна діяльність князів Острозьких, які обороняли Православну Церкву і права віруючих цієї Церкви проти експансії католицизму і у зв'язку з цим намагалися організувати союзи с протестантами. Автори аналізують об'єктивні та суб'єктивні фактори, що привели до зближення православних протестантів у цій боротьбі, та наслідки протистояння представників різних християнських віросповідань на теренах Речі Посполитої в XVI-XVII ст. Для розуміння складної релігійної ситуації сучасної України здійснюється певний історичний екскурс, аналізуються головні тенденції, характерні для минулих часів, та виявляються подібні явища в нинішніх умовах. Показано, що у формуванні релігійних засад української культури визначна роль належить видатному діячу вітчизняної історії, магнату Костянтину Василю Острозькому. Головною метою Унії, якщо б вона відбулася, він вважав не підкорення православних Папі Римському, а заснування шкіл, освіту проповідників і поширення релігійної освіти загалом.

Наполягання на єдності віруючих у сповідуванні істинного християнства, гостра критика агресивної політики католицизму щодо інших християнських віросповідань, готовність чинити опір цим зазіханням (в тому числі і збройний), дорікання за лицемірство католицьких священиків, що не дотримуються своїх же настанов (зокрема целібату), - все це робить К. В. Острозького активним оборонцем православної віри, так би мовити, «лицарем православ'я .

Показана наявність своєрідних латентних протестантських мотивів у світогляді К. Острозького. Виявлені екуменічні аспекти діяльності князя К. Острозького. Змальовані драматичні подієві перипетії боротьби князя К. В. Острозького щодо захисту православної віри. Проаналізовані причини невдалого спротиву князів Острозьких експансіонізму Римокатолицької церкви. Виявлено аналогії релігійної боротьби минулих часів і нинішньої релігійної ситуації в Україні. Розглянуті можливі перспективи еволюції релігійної ситуації в сучасній Україні у зв'язку з налаштуванням чималої частини громадян нашої держави на західноєвропейські цінності.

Ключові слова: прозелітизм, католицизм, протестантизм, православ'я, віросповідання, конфесія.
\end{abstract}

«Те, щзо було, є те саме, щуо буде;

те, щуо зробилось, є те саме, щуо зробиться.

Нема нічого нового під сонцем»

Святе Письмо. Проповідник. 
Постановка проблеми. Для розуміння складної релігійної ситуації сучасної України варто здійснити певний історичний екскурс, проаналізувати головні тенденції, характерні для минулих часів, та виявити подібні явища в нинішніх умовах. У формуванні релігійних засад української культури визначна роль належить видатному діячу вітчизняної історії, магнату Костянтину Василю Острозькому. В ситуації протистояння християнських віросповідань у XVI-XVII ст. (католицького i протестантського, католицького, греко-католицького і православного) він виявив надзвичайну активність у публічному житті. Метою статmі є з'ясування об'єктивних та суб'єктивних факторів що привели до зближення православних і протестантів у цій боротьбі, та наслідків протистояння представників різних християнських віросповідань.

Аналіз останніх досліджень і публікацій. Діяльності Костянтина Острозького, в тому числі стосовно релігійної сфери, присвячено чимало праць $[4 ; 5 ; 6 ; 9 ; 11 ; 13 ; 14$ та iн.], проте лише поодинокі автори звертають увагу на його цікавість до протестантського віросповідання i намагання налагодити відносини 3 протестантськими діячами та спільнотами в опорі наступу Римо-Католицької Церкви i щойно народженої Греко-Католицької Церкви на традиційне для українських земель православ'я. Чималий внесок у цю тему здійснила $T$. Шевченко, яка в рядi статей аналізує роль Костянтина В. Острозького $i$ його сина Олександра у спільних 3 протестантами антикатолицьких діях [12]. Однак і в цих працях не звертається належна увага на причини і наслідки цієї діяльності князів. Між тим, важко зрозуміти причини загострення релігійної ситуації в цьому регіоні, якщо лишити осторонь успіхи західноєвропейської Реформації і страх Ватикану втратити вплив на значну частину своєї пастви. Виглядає доволі дивно, коли в окремих працях [14], зазначаючи толерантне ставлення К. Острозького до інших віросповідань (мусульманського, католицького), автори навіть не згадують про його зацікавлення протестантизмом. Так, польський дослідник Т. Кемпа зазначає: «Прив'язаність до православ'я не заважала Острозькому жити у згоді 3 людьми інших віросповідань і релігій. Татари були істотною частиною приватних збройних сил Острозьких не тільки в часи життя гетьмана. Мали вони гарантовану можливість сповідування своєї мусульманської віри також у збудованих за згодою Острозького мечетях. Позитивним було також ставлення князя Костянтина до католиків» [14, с.19]. Важко погодитися (і цьому є чимало свідчень), що ставлення гетьмана до католиків було завжди, м'яко кажучи, толерантним. Це суперечить його ролі, яку він насправді відігравав у боротьбі з РимоКатолицькою Церквою, за права православних віруючих, до яких належав. У статті українських дослідників С. Повторевої і В. Савельєва [10] здійснено докладний аналіз причин і наслідків Унії, зокрема змісту прийнятих церковними ієрархами артикулів, 3 урахуванням ролі протестантизму в релігійних подіях цього періоду на українських землях. Проте в цій праці нічого не говориться про організаційну діяльність князів Острозьких серед протестантських громад, хоча стверджується факт і розглядаються фактори зростаючої популярності протестантизму серед східних слов'ян Речі Посполитої.

К. Острозький вважав грецьку віру єдино правильною, правдивою, засуджував прагнення католиків відірвати благочестивих православних від їх віри, негативно оцінював навернення православних священиків до іншого віросповідання, вважав це великим гріхом і облудою. «Багато - висловлював ся Острожський - в обивателів тутешнього краю держави його милости мого короля, послушних святій східній Церкві, вважають мене передовим чоловіком в православ'ю, хоч я сам уважаю себе не більшим, як рівним між іншими щодо правовірности; з тої причини бою ся, щоб я не став виноватим перед Богом і вами; тому звіщаю вас про се, про що напевне дізнав ся я, бажаючи разом з нами одностайно стати проти супостатів, щоби з Божої помочи і при 
вашій дбалости ті, що приготовили на нас сїти, самі в ті сїти попали. Що може бути соромніше і безправнїше, коли шість або сім злодіїв відпало від своїх пастирів, котрі їх настановили, а вважаючи нас безсловесним товаром, важать ся самовільно відривати нас від правди й вводити нас в загибель з собою?» [7, с.182]. В цих словах К.В. Острозького засуджуються вчинки священиків (М. Рогози, К. Терлецькиого, А. Потія та інших), що були не задоволені діяльністю константинопольського патріарха Єремії і православних братств (до яких входили не лише священики, але й світські люди) і хотіли перейти у підпорядкування Папи Римського. Католики намагалися схилити К.В. Острозького до прийняття католицької віри або приєднання до Унії, яку в той час активно готували. Ці наміри виразно проглядаються у листуванні між ним і Адамом Потієм, свояком Острозького, колишнім православним світським чоловіком, який перейшов у католицтво і в 1593 р. став володимирським єпископом. Однак князь Костянтин не бажав тієї Унії, яку планував Рим. Він міг прийняти Унію лише у разі, якщо інші православні Церкви, в тому числі й Московська, пішли би на це. Крім того головною метою Унії, якщо б вона відбулася, він вважав не підкорення православних Папі Римському, а заснування шкіл, освіту проповідників і поширення релігійної освіти загалом.

До своєї боротьби з позицією і діяльністю католицизму князь прагнув залучити протестантів. У листуванні з А. Потієм К. Острозький не міг приховати своєї давньої симпатії до протестантизму. Він говорив, що подібно до того, як це відбулося у протестантів, треба чимало змінити в існуючих церковних обрядах, таїнствах, в церковному управлінні. Чимало цих традицій і звичаїв, на його думку, були не чим іншим, як людськими вигадками.

К.В. Острозький просив польського короля Сигизмунда скликати собор, на якому були би присутні не тільки духовні, але й світські особи. Король однак не хотів цього, умовляв магната приєднатись до Унії, мотивуючи це тим, що константинопольський патріарх, який був главою православної Церкви в Україні, перебував під владою мусульманської держави. Це ображало К. Острозького як православного віруючого. Ведучи боротьбу за православ'я він намагався створити союз 3 протестантами. 3 цією метою князь відправив свого посланця до протестантської спільноти в м. Торунь i пропонував спільно виступити проти папізму. «Всі, що признають Отця й Сина й сьв. Духа, люди одної віри; - зазначав К.В. Острозький в листі до польського короля, - як би люди з шаною гледїли, як їх брати славлять Бога кожний після свого сумлїня, то менше було би сект і наук на сьвітї. Ми повинні злучити ся з усїми, хто тілько віддаляє ся від латинської віри й сприяє нашій долї; всї християнські ісповіданя повинні боронити ся проти «папежників». Його королівська милість не схоче допустити нападу на нас, тому що в нас самих може явити ся двадцять а бодай пятьнайцять тисяч оружних людий, а панове папежники можуть взяти верх над нами хиба числом тих кухарок, котрих ксьондзи держать у себе замісць жінок» [7, с.183].

У цьому листі можна побачити виразний вплив ідей і практики євангелістів на ставлення до католицизму активного оборонця православної віри, яким постає в історії України К.В. Острозький. Це наполягання на єдності віруючих у сповідуванні істинного християнства, гостра критика агресивної політики католицизму щодо інших християнських віросповідань, готовність чинити опір цим зазіханням (в тому числі і збройний), дорікання за лицемірство католицьких священиків, що не дотримуються своїх же настанов (зокрема целібату). Відомо, що король, прочитавши цього листа, особливо обурився глузливими словами князя про кухарок, сприйнявши це як образу віри, яку він сам сповідував [7, с.183].

Найбільш активним супротивником князів був католицький священик, організатор єзуїтських коледжів П. Скарга, який доводив переваги католицької Церкви 
над православною, використовуючи витончені богословські аргументи. Головною тезою П. Скарги було те, що грецька і руська Церкви не мають у собі ані собору святих, ані науки, ані істинних пастирів, і що все в ній зіпсовано через відділення від папського престолу. В своїй програмній праці «O jednosci kosciola Bozego» він вказував декілька причин відступлення східної Церкви від Папи Римського. Це гордість і зверхність константинопольських патріархів, що боролися за першість у християнському світі, перевищення влади візантійських імператорів, що відкинули владу римської Церкви, залежність руської Церкви від московського царя, невігластво священиків руської Церкви, недосконалість слов'янської мови, необхідність з боку грецьких патріархів платити данину турецькому султану тощо [3, с.125-126]. Цьому, на його думку, марнотратству православної Церкви П. Скарга протиставив турботу Папи про бідних і позбавлених засобів русинів, для яких на власні кошти Папи було організовано семінарію.

Надзвичайно пристрасним опонентом П. Скарги був афонський монах Іван Вишенський, який у полеміці з єзуїтом радив супротивнику «до поганських учителей и до латинское хитрословие лжи не ходи, бо веру загубиш» [3, с.170]. Щодо мови православний полеміст зазначав «Ведай же о том, Скарго, хто спастися хочет и освятитися прагнет, если до простоті и правді покорнаго язика словенського не доступит, ани спасення, ани освещения не получит» [3, с.171].

Аргументи П. Скарги не подіяли на князя К. Острозького. Особливо образливо було сприйнято ним нагадування про залежність грецьких патріархів від турецького правителя, якому регулярно сплачували данину. Князь організовував цілу низку дій спротиву діяльності католиків особливо в період після прийняття Унії. Одним 3 яскравих епізодів протистояння католиків і православних стали два конкуруючих собори, що відбулися восени 1596 року в Бересті. Один собор був скликаний під егідою польського короля і мав на меті остаточне прийняття Унії. Як відомо, саме на ньому прийнято рішення, яке набуло докладного виразу в документі «Артикули» [1; 10]. У двох засіданнях цього собору взяли участь з боку православних К.В. Острозький, його сини Януш і Олександр, які прибули з озброєним супроводом, з боку католиків - єзуїти Петро Скарга, Юстус Раб, Мартин Латерна. Слід відзначити, що у боротьбі К.В.Острозького з католицизмом і Унією, в контактах з протестантами активну участь брав саме наймолодший син К. В. Острозького Олександр. Він був єдиним серед дітей князя, який залишився до кінця свого недовгого життя православним.

Другий собор скликав К. В. Острозький, і на ньому були присутні посланці константинопольського патріарха - Никифор і олександрійського патріарха - Кирил, а також два східні архімандрити і два українські єпископи, сербський митрополит, кілька українських архімандритів і протопопів, а також двісті світських людей зі шляхти. Тобто це був цілком канонічно чинний собор. Відсутній на соборі київський митрополит повідомив, що він разом 3 кількома єпископами перейшов у підпорядкування західній Церкві. Делегати обох соборів засудили одне одних i звернулися до короля. Король прийняв бік уніатів та звелів ув'язнити намісника константинопольського патріарха Никифора, доля якого склалася трагічно (він помер у в’язниці), а К. Острозький не зміг його захистити [7, с.186-188].

Важливо підкреслити, що ці події докладно описані чеським протестантом i приятелем К.В. Острозького Мартином Броневським у полемічному творі «Ekthesis», де автор гостро дискутує з П. Скаргою. У свою чергу, П. Скарга невдовзі дав свою відповідь у творі «Synod brzeski i jego obrona». Завершенням суперечки стала інша праця М. Броневського «Apokrisis», визнана найвидатнішим полемічним православним твором. Про гостроту полеміки свідчить і той факт, що всі ці праці написано в одому й тому ж 1597 році, дуже скоро після обох соборів і тих драматичних подій, 3 ними 
пов'язаних. К. В. Острозький нагородив автора-протестанта, який виявив такий хист в обороні православ'я, містечком з кількома селами [12].

Після укладення Берестейської унії за ініціативою К. В. Острозького відбувається подальше зближення православних віруючих з протестантами. Значну підтримку князю у цьому процесі надавав його зять - литовський магнат Криштоф Миколай Радзівіл, що був лідером кальвіністської спільноти. Він став союзником свого православного родича i посередником у контактах з іншими протестантськими громадами. Так, у 1599 р. у Вільні відбувся спільний з'їзд протестантів (кальвіністів, лютеран і чеських братів) та православних. У з'їзді з православного боку взяли участь Костянтин та Олександр Острозькі. На цій зустрічі було представлено проект князя К.В. Острозького щодо об'єднання з протестантами в галузі релігії і політики. Цим документом передбачалося, що князь також $є$ посередником між олександрійським патріархом та євангелістами щодо допомоги у поєднанні Церков [12].

Можна вказати такі істотні причини прагнення Костянтина Острозького до союзу с протестантами. Перш за все, протестанти мали успішний досвід протистояння католицизму в Західній Європі. По-друге, православні і протестанти не мали істотних розходжень як у віросповідних принципах, так і в особливостях побудови церковного життя. Так, К. Острозького вочевидь могла приваблювати опора протестантизму на внутрішню духовність, на віру, а не на значною мірою матеріальну підтримку (ділами) Церкви. В протестантів утворювалися різні центри управління Церквою, що було для православ'я в тих умовах цілком позитивним фактором. Крім того, завзятий прозелітизм Римо-Католицької Церкви, що створила 3 цією метою Унію, до якої пристали деякі колишні православні ієрархи, страшенно обурював К. Острозького і його прихильників. Князь вважав їх зрадниками і віровідступниками.

В останні роки свого життя князь К. Острозький разом із сином Олександром, який з батьком на березневому сеймі 1603 р. відіграв провідну роль у відстоюванні прав православних віруючих, досягли деяких успіхів у боротьбі 3 католиками i уніатами. Їм вдалося відвоювати Києво-Печерську архімандрію в уніатів. Король Сигізмунд III погодився на обрання Києво-Печерського архімандрита монахами монастиря та світськими аристократами Київщини. Православним було обіцяне припинення процесів, що вели проти них уніати. Завдяки активній позиції К.В. Острозького Києво-Печерська архімандрія не перейшла до уніатського митрополита I. Потія, залишалась у православних. Архімандритом став підтриманий Острозькими князями та всією православною спільнотою православний священик Єлисей Плетенецький [12]. I це слід визначити беззаперечною перемогою православних у боротьбі із західною Церквою.

Здоров’я Костянтина Острозького погіршувалося і тому естафету у церковних справах перейняв його син Олександр. Князь Костянтин замислив проект, за яким він планував своє посередництво між олександрійським патріархом та протестантами, що надіслали йому листа, де визначалися їх спільні догматичні позиції з православними. Олександр мав взяти активну участь у цій справі. Однак ініціатива Костянтина не мала успіху через те, що патріарх не схвалив цих намірів. Активність Олександра викликала негативну реакцію в ієрархів Римо-Католицької Церкви та в уніатів. Крім того, були й інші причини еволюції ставлення католиків до молодого князя. До настання чинності Берестейської унії Олександр мав добрі стосунки з католиками, допомагав матеріально єзуїтському дому, розташованому в його маєтку в Ярославі. Князі Острозькі категорично не сприйняли Унії, активно боролися проти неї, однак завадити ій не змогли. Після прийняття Унії Олександр припинив платити єзуїтам, не підтримав їх планів будівництва бурси для бідних учнів. В 1600 р. згоріла більша частина міських будівель Ярослава, зокрема приміщення єзуїтської колегії і Церкви. Князь Олександр

(C) С. М. Повторева, I. І. Старовойтова, 2019 
не лише не допоміг єзуїтам у відбудові, навіть чинив спротив їх намаганням відновити свою діяльність. Відповідно єзуїти були невдоволені такою ситуацією. Вони висловлювали побоювання, що князь Олександр може забрати в них будівлі їх храму, колегії і школи та передати православним, та й взагалі хоче, щоб єзуїти залишили Ярослав. Князь опікувався місцевою православною Церквою та православним міщанським братством, членом якого був і мав право обирати чотирьох керівників братства. Деякі ярославські єзуїти сподівалися, що ситуація може змінитись на краще по смерті князя. Як пророчо передбачили ярославські єзуїти, за кілька років Олександр Острозький раптово помер. Це відбулось у селищі Красне на Тернопільщині 13 грудня 1603 р. Як писали єзуїт Ян Велевицький у хроніці «Dziennik domu św. Barbawy w Krakowi» та нунцій Клаудіо Рангоні, причиною смерті було отруєння. Це одна з версій причини передчасної смерті Олександра, хоч і доволі правдоподібна. В усякому разі, в середовищі католиків спостерігалося певне задоволення через смерть молодого князя, який був останньою серйозною перешкодою 3 боку союзу православних 3 протестантами католицькій експансії.

Релігійна ситуація в родинах князів Острозьких склалася не на користь православ'я і доволі трагічно для батька. Він пережив свого сина Олександра, який готувався активно обороняти православ'я і налагоджувати в цій боротьбі подальші контакти 3 протестантами. Дружина князя Олександра Анна, що була 3 родини католиків, всіляко сприяла посмертній католизації пам'яті про чоловіка. Вона наказала відправляти щорічні меси в Ярославі, виплатила єзуїтам борги Олександра, побудувала будинок для бурси бідних студентів, загалом щедро жертвувала кошти на потреби ордену єзуїтів. Ще деякий час до своєї смерті опікуном його малолітніх дітей і дружини Олександра залишився його батько Костянтин, а вихователем синів (онуків Костянтина) був Лаврентій Зизаній, відомий православний полеміст, проповідник, автор першого підручника церковнослов'янської мови. Його було звільнено одразу після смерті Костянтина Острозького у 1608 р. Найстарший син Януш ще за життя батька прийняв, як і всі його доньки, католицтво. Донька Анна-Алоїза, володарка Острогу, «визначала ся завзятою нетерпимістю для віри прабатьків своїх» [7, с.192].

Відповідно зазнала неуспіху і справа, якій присвятили значну частину життя i діяльності Костянтин та Олександр. Вони не змогли оборонити православ'я. Унія, яка спочатку була посередницьким способом схилити вищу українську верству до католицизму, мала неоднозначні наслідки для історії і культури України. Представники вищої верстви вже не мали потре6и у такому посередництві, вони «стали чистими католиками; унія лишила ся тілько способом, щоби знищити в громадї останків народу православної віри й української народності» [7, с.192]. Уніатська або греко-католицька віра не могла бути рівною з вірою панства і стала «приналежностю простого народу», «вірою низкою, простонародною, негідною вищої верстви» [7, с.192]. Православ'я ж вважалося надзвичайно низьким віровизнанням, вірою «негідних хлопів», що постала «не більше, як марне ісповіданє понеханих недовірків, для котрих і за гробом немає спасіння» [7, с.192]. Однак, в історичній перспективі зусилля князів Острозьких не були марними. Як ми знаємо, внаслідок повстання і війни під керівництвом Богдана Хмельницького православ'я повернулося на західні терени України і посіло належне місце в іiі історії та культурі.

В сучасній релігійній ситуації України можна відзначити ряд моментів подібності тогочасної і нинішньої релігійної ситуації. Існування різних гілок православ'я спостерігається із самого початку набуття української незалежності. До недавніх часів ці гілки, хоч і в певній конкуренції, врешті решт розподілили сфери впливу, i суперечності розв'язувалися в більшості мирним шляхом за винятком окремих епізодів. Успішно розвивався екуменічний рух, в тому числі і з представниками протестантських 
громад. Нині ж релігійний процес в нашій країні набув гострих форм. Протистояння ущільнюється, особливо в православ'ї. Розколи спостерігаються не лише між різними гілками православ'я, але й в середині їх. Так, митрополит Переяслав-Хмельницький і Винницький, вікарій Київської митрополії УПЦ (МП) Олександр (Драбинко), який сприяв створенню Православної Церкви України (ПЦУ), писав: «УПЦ - велика структура. Тому серед iї вірних - включно з бізнесменами - напевно, є й прихильники автокефального статусу. Однак це люди у своїй більшості помірковані. I ніхто з них не бажає штучно форсувати події... В Україні росте молоде, свідоме своєї національної ідентичності покоління. I для цього покоління зв'язок з Росією, - разом зі зв'язком церковним - це архаїзми. Ми рухаємося повільно, але певно. Нам не потрібні проплачені масові акції або скандальні видання» [2]. Миролюбний стиль мовлення Олександра в цьому інтерв'ю, що він дав журналістові газети «Експрес», змінюється, коли він дуже негативно і пристрасно відгукується про діяльність народного депутата Вадима Новинського, який звинуватив митрополита у розколі православ'я. До речі, В. Новинського внесено у скандальний сайт «Миротворець», який засуджено європейськими журналістами і міжнародними організаціями, що захищають свободу слова. Якщо ієрарх цієї гілки українського православ'я доволі поміркований у своїх висловлюваннях, то з боку іншої гілки православ'я УПЦ КП спостерігалася досить активна діяльність щодо наступу на інше православне віросповідання (захоплення храмів, інші види насильства, в тому числі за допомогою людей зі зброєю). У протистоянні православних беруть участь і представники УГКЦ, також втручаються i державні особи, порушуючи цим конституційний принцип свободи совісті. Відроджуються плани поступового скасування православ'я під гаслами, що це опора «руського міра». При цьому не дуже зважають ані на Конституцію України, ані на права і бажання віруючих, ані на неприпустимість порушення заповідей християнства. Так, під час зустрічі у липні 2018 р. голови УГКЦ Святослава Шевчука 3 представниками посольства США і колишнього очільника УПЦ КП Філарета грекокатолицький ієрарх зазначив, що його Церква не втручатиметься в процес об'єднання православ'я в Україні. Однак, на його думку, об'єднання - це лише перший крок (?!) до єдності християнської Церкви України, адже справжньою вірою є та, де Папа [8]. Чи не нагадують подібні думки ідеї праці «Про єдність Костьолу Божого» ентузіаста покатоличення православних українців Петра Скарги? При серйозному аналізі ситуації не так важко зрозуміти, що під гаслами єдності православ'я і створення єдиної помісної православної Церкви України насправді стимулюються прозелітизм, розкол, ворожнеча у протистоянні, в якому все більш активну участь беруть греко-католицькі ієрархи. Як і колись, в цей складний болючий процес втручаються представники інших держав, що переслідують власні інтереси, хоч прикривають це турботою про народ України.

Висновки. У боротьбі за збереження Православної Церкви і за права iï вірних магнати Острозькі намагалися спиратися на підтримку протестантів, які мали на той час в Західній Європі успішний досвід протистояння католицизму. Причинами активізації наступу католицтва і прозелітизму на територіях проживання східного слов'янства були інтереси римського престолу і уряду Речі Посполитої, які вдалися до розколу православ'я і утворення Унії. Неуспіх спротиву експансіонізму РимоКатолицької Церкви князів Острозьких та їх послідовників у союзі з протестантами пояснюється значною мірою потужним рухом Контрреформації, організованої римським престолом. Це, на наш погляд, стало однією з головних причин утворення Унії як перехідного етапу до повного знищення православ'я, тотального покатоличення слов'янства західних українських земель та Білорусі.

Слід відзначити ряд моментів подібності тогочасної і нинішньої релігійної ситуації в Україні. Спостерігається наступ однієї з гілок православ'я при підтримці 
УГКЦ і державних осіб на інше православне віросповідання. При цьому під гаслами єдності православної Церкви України практикуються дії, що ведуть до внутрішнього розколу спільнот, ворожого протистояння. Застосовуються методи, не сумісні із заповідями християнства. В релігійному процесі все більш активну участь беруть греко-католицькі ієрархи при підтримці Риму. Як і колись, в ослабленій боротьбою верхівки країні представники інших держав намагаються здобути вигоду і зовсім не прагнуть насправді допомогти українському народові.

Перспективи дослідження. Розглянуті питання набувають значної актуальності у зв'язку 3 налаштуванням чималої частини громадян нашої держави на західноєвропейські цінності, розширенням взаємозв'язків українських спільнот, в тому числі релігійних, із західноєвропейськими спільнотами, функціонуванням різних протестантських віросповідань на теренах України. Тому важливо ретельно досліджувати події спільної історії, в якій є чимало білих плям, виявляючи моменти єдності і співпраці, також певні суперечності і конфлікти, що впливають на соціальнополітичні та конфесійні процеси нашої країни сьогодні.

\section{СПИСОК ВИКОРИСТАНИХ ДЖЕРЕЛ}

1. Артикули, на які згоди потребуємо від панів римлян, перш ніж до єдності з Церквою римською приступимо. - Людина і світ, 1996.- №1-2. - С. 34-38.

2. Великі таємниці УПЦ МП. Інтерв'ю 3 митрополитом ПереяславХмельницьким і Винницьким, вікарієм Київської митрополії УПЦ МП Олександром (Драбинко). - Експрес. - 2016. - 21-28 липня.

3. Замалеев А.Ф. Отечественные мыслители позднего средневековья (конец XIV - первая треть XVII в.) / А.Ф.Замалеев, В.А.Зоц. - К.: Лыбидь, 1990. - 176 с.

4. І Іларіон. Князь Костянтин Острозький і його культурна праця: історична монографія / Іларіон. - К.: Світязь, 1992. - 216 с.

5. Ковалів О. Вітольд-Йосиф. «Руський Сципіон» - гетьман Костянтин Іванович Острозький у польській історіографії. / О.Вітольд-Йосиф Ковалів // Wołanie z Wołynia (Волання з Волині). - 2010. - Ч. 6 (97). - С. 37-43.

6. Ковалюк М. Князь Костянтин Іванович Острозький в історії ЦентральноСхідної Свропи / М.Ковалюк // Wołanie z Wołynia (Волання з Волині). -2010. -Ч.6 (97). - C. 35-36.

7. Костомарів М. Істория України в життєписах визначнійших єї діячів / М.Костомарів / пер. О.Барвінського. Львів: НТШ, 1918. 493 с.

8. Марченко А. Владыка с ноутбуком / Марченко А. - Сегодня. - 2011. - 20 марта.

9. Паламарчук О. Князь Костянтин Острозький як оборонець українського православ'я. [Електронний ресурс]. - Режим доступу: http://narodna.pravda.com.ua/history/4ae4b9da9d1bf/

10. Повторева С.М. Роль УГКЦ у захисті прав і духовному формуванні культури українського народу / С.М.Повторева, В.П.Савельєв // Гуманізм і духовність в контексті культури. - Дрогобич, 1995. - Кн.ІІ. - С.78-85.

11. Ульяновський В. «Славний для всіх часів чоловік»: князь Костянтин Іванович Острозький : монографія // В.Ульяновський. - Острог: Вид-во Національного ун-ту «Острозька академія», 2009. - Вип. 2. - 168 с.

12. Шевченко Т. Острозькі та єзуїти у році 1596 і після / https: // risu.org.ua/ua/index/monitoring/religious_digest/41371

13. Яковенко Н.М. Костянтин Острозький / Н.М.Яковенко // Волинь: всеукр. сусп.-політич., літ.-мистецьк. часопис. - Луцьк: [Волинська обласна друкарня], 2007. № 8. - C. 91-100. 
14. Tomas z Kempa. Działalnoś ćhetmana Konstantego Iwanowicza Ostrogskiego na polu prawosławia. [Електронний pecypc]. - Режим доступу: http:// pdf.kamunikat.org/download.php?item=2166-2.pdf

\title{
БОРЬБА МАГНАТОВ ОСТРОЖСКИХ ПРИ ПОДДЕРЖКЕ ПРОТЕСТАНТОВ ЗА СОХРАНЕНИЕ ПРАВОСЛАВНОЙ ЦЕРКВИ: УРОКИ ИСТОРИИ
}

\begin{abstract}
Аннотация: Предметом исследования статьи является религиозная деятельность князей Острожских, которые защищали Православную Церковь и права верующих этой Церкви против экспансии католицизма и в этом процессе стремились организовать союзы с протестантами. Авторы анализируют объективные и субъективные факторы, которые привели к сближению православных и протестантов в этой борьбе, и последствия противостояния представителей различных христианских вероисповеданий на землях Речи Посполитой в XVI-XVII ст. Выявлены аналогии религиозной борьбы прошедших времен и нынешней религиозной ситуации в Украине.
\end{abstract}

Ключевые слова: прозелитизм, католицизм, протестантизм, православие, вероисповедание, конфессия.

\section{STRUGGLE OF MAGNATES OSTROGSKY WITH THE SUPPORT OF PROTESTANTS FOR THE PRESERVATION THE ORTHODOX CHURCH: THE LESSONS OF HISTORY}

Summary: The subject of study of the article is the religious activities of the Ostrozky princes, who defended the Orthodox Church and the rights of the Church's believers against the expansion of Catholicism, and therefore sought to form alliances with Protestants. The authors analyze the objective and subjective factors that led to the convergence of Orthodox and Protestants in this struggle, and the consequences of the confrontation of representatives of different Christian denominations in the territory of the Polish-Lithuanian Commonwealth in the XVI-XVII centuries. To understand the complex religious situation of modern Ukraine, a certain historical excursion is made, the main tendencies characteristic of past times are analyzed, and similar phenomena are revealed in the present conditions. It is shown that the prominent role in the formation of religious foundations of Ukrainian culture belongs to the prominent figure of national history, the magnate Konstantin Vasily Ostrozky. The main purpose of the Union, if it would took place, was not the subjugation the Orthodox to the Pope, but the founding of schools, the preacher's education, and the spread of religious education in general.

Insistence on the unity of believers in the practicing of true Christianity, sharp criticism of Catholic aggressive policy towards other Christian denominations, readiness to resist this encroachment (including the armed ones), reproach for the hypocrisy of their Catholic priests, especially the priests, all this makes K.V. Ostrozky an active defender of the Orthodox faith, so to speak, "the knight of Orthodoxy". Insistence on the unity of believers in the practicing of true Christianity, sharp criticism of Catholic aggressive policy towards other Christian denominations, readiness to resist this encroachment (including the armed ones), reproach for the hypocrisy of their Catholic priests, especially the priests, all this makes K.V. Ostrozky an active defender of the Orthodox faith, so to speak, "the knight of Orthodoxy".

The presence of a kind of latent Protestant motives in K. Ostrozky's outlook is shown. Ecumenical aspects of the activity of Prince K. Ostrozky are revealed. The dramatic events of the struggle of Prince K.V. Ostrozky for the protection of the Orthodox faith are depicted. The reasons for the unsuccessful resistance of the Ostrozky princes against expansionism of the Roman Catholic Church are analyzed. The analogies of the religious struggle of the past times and the present religious situation in Ukraine are revealed. Possible perspectives of the evolution of the religious situation in modern Ukraine in connection with the adjustment of a large part of our country's citizens to Western European values are considered.

Key words: belief, Catholicism, confessions, Protestantism, proselytism, Orthodoxy.. 